\title{
PKM Pengolahan Kaki Naga Ikan Air Tawar untuk Meningkatkan Gizi Keluarga
}

\author{
Firlianty* dan Yetrie Ludang \\ Universitas Palangka Raya Jl. Yos Sudarso, Kalimantan Tengah. Indonesia \\ *Penulis Korespodensi : firlianty80@gmail.com
}

\begin{abstract}
Abstrak
Kelurahan Pahandut adalah salah satu kelurahan di wilayah Kecamatan Pahandut, Kota Palangka Raya dengan topografi dataran rendah. Masyarakatnya secara umum bertempat tinggal di bantaran sungai Kahayan, dengan model rumah panggung terbuat dari kayu dan akses jalan didominasi oleh jembatan kayu (titian), sehingga tidak mempunyai lahan pekarangan yang memadai. Sepanjang tepi sungai terdapat budidaya ikan dalam keramba apung yang diletakkan di tepi sungai dengan jenis ikan bervariasi seperti ikan mas, nila, patin dan bawal, namun hasil budidaya ikan jika sudah layak menjadi ikan konsumsi maka akan langsung dijual dalam bentuk segar, sehingga nilai ekonominya masih terbatas. Untuk itu diperlukan peningkatan pengetahuan (sains) dan ekonomi masyarakat melalui kegiatan-kegiatan yang melibatkan peran aktif masyarakat. Metode dari pelaksanaan kegiatan ini adalah dengan penyuluhan dan pelatihan praktek secara langsung. Diversifikasi pengolahan kaki naga ikan air tawar ini diharapkan mampu meningkatkan gizi masyarakat dan juga dapat menambah pengetahuan keterampilan masyarakat untuk berbagai olahan dari ikan air tawar.
\end{abstract}

Kata Kunci : Kaki naga, Pengolahan Ikan, Peningkatan gizi

\section{PENDAHULUAN}

Pendapatan per kapita penduduk Kota Palangka Raya pada Tahun 2015 adalah sebesar Rp 43,4 juta naik sebesar 11,46\% dari tahun sebelumnya. Beban tanggungan setiap 100 orang penduduk mencapai 39 orang. Mata pencaharian penduduk sebagian besar berprofesi sebagai buruh lepas, nelayan dan wiraswasta. Jumlah Rumah Tangga Perikanan Budidaya Keramba yang diusahakan di sepanjang Sungai Kahayan, pada Tahun 2016 sebesar 1.217 buah (89\%) dari seluruh jenis perikanan budidaya lainnya sehingga potensi untuk dikembangkan lebih lanjut (BPS, 2017). Umumnya tingkat pendapatan penduduk ratarata tiap bulannya hanya cukup untuk memenuhi kebutuhan hidup sehari- hari dengan tingkat pengeluaran yang disesuaikan dengan pendapatan yang diperoleh. Sarana perekonomian yang terdapat di Kelurahan Pahandut meliputi pasar tradisional, toko kelontong dan warung makan dan BRI.
Kelurahan Pahandut adalah salah satu kelurahan di wilayah Kecamatan Pahandut, Kota Palangka Raya dengan topografi dataran rendah, berawa-rawa dan selalu terlimpasi oleh luapan air sungai Kahayan dalam waktu beberapa bulan bila musim banjir tiba. Matapencaharian penduduk sebagian besar sebagai buruh harian lepas, nelayan, wiraswasta/pedagang dan sebagian kecil sebagai PNS (guru) (BPS, 2017). Lokasi kegiatan Pahandut Seberang merupakan salah satu wilayah pemukiman yang cukup padat di kelurahan Pahandut adalah dimana masyarakatnya pada umumnya bertempat tinggal di bantaran sungai Kahayan, dengan model rumah panggung yang terbuat dari kayu dan akses jalan sempit didominasi oleh jembatan kayu (titian), sehingga tidak mempunyai lahan pekarangan yang memadai sebagai tempat budidaya tanaman. Sebagian warga masyarakat yang berprofesi sebagai nelayan tangkap maupun nelayan budidaya ikan dalam keramba apung yang diletakkan di 
tepi sungai dengan jenis ikan bervariasi seperti ikan mas, nila, patin dan bawal, dimana hasil tangkapan ikan langsung dijual dalam bentuk segar, sehingga nilai ekonominya masih terbatas. Dilain pihak, peningkatan gizi masyarakat masih perlu ditingkatkan melalui penyuluhan nilai gizi ikan dan menumbuhkan kreativitas dalam mengolah produk ikan untuk keperluan konsumsi dan usaha kuliner sebagai sumber pendapatan keluargaTingkat pendidikan masyarakatnya sebagian besar hanya sampai tingkat SD-SMP, sedikit sekali yang lulus SMA bahkan Sarjana (Monografi Kelurahan Pahandut, 2017). Kondisi tingkat pendidikan ini menyebabkan kesadaran akan arti hidup sehat serta pola pikir masyarakatnya sangatlah terbatas

Keterbatasan diversifikasi pengolahan produk berbahan dasar ikan bila hasil tangkapan dan produksi ikan keramba banyak khususnya ikan patin menyebabkan harga jual rendah. Untuk mengatasi permasalahan tersebut diperlukan adanya pelatihan/pendampingan bagi masyarakat mengingat antusiasme warga sangat tinggi untuk mengadopsi pengetahuan tersebut, dimana kegiatan ini akan bersinergi dengan bentuk kegiatan lain yang sudah berjalan.

Tujuan kegiatan pengabdian kepada masyarakat ini untuk membantu mengatasi permasalahan yang dihadapi oleh masyarakat Pahandut seberang dengan memberikan pelatihan/pendampingan: 1) Pendampingan teknologi diversifikasi pengolahan daging ikan menjadi Kaki Naga ikan patin-sayuran 2) Promosi kegiatan Kampung Literasi dengan kegiatan-kegiatan yang dapat meningkatkan kualitas sains dan ekonomi masyarakat di sekitarnya.

\section{METODE PELAKSANAAN}

\section{Waktu Pelaksanaan}

Waktu pelaksanaan kegiatan PKM pembuatan Kaki Naga ikan air tawar ini dilaksanakan 21 November 2020, pelaksanaan kegiatan pengabdian dengan sesuai dengan protokol kesehatan karena masih dalam kondisi pandemic covid 19.

\section{Metode Kegiatan}

Metode pendekatan yang diberikan kepada mitra adalah pendampingan, pelatihan dan pengolahan produk hasil perikanan. Kegiatan pendampingan sesuai kesepakatan bersama untuk mengatasi permasalahan mitra adalah dengan pendampingan teknologi pengolahan hasil ikan menjadi Kaki Naga ikan yang berbahan dasar daging ikan gabus.

\section{Evaluasi Keberhasilan Kegiatan}

Pada akhir kegiatan akan dilakukan evaluasi terhadap kegiatan program dengan indikator pada, pengetahuan masyarakat terhadap kesehatan lingkungan, gizi dan kesehatan keluarga meningkat, mampu memperbaiki ekonomi keluarga dengan mampu membuat diversifikasi olahan ikan.

\section{HASIL DAN PEMBAHASAN}

Kegiatan Pengabdian ini dilaksanakan dengan memperhatikan protokol kesehatan dimana dilakukannya Pelatihan Pengolahan Kaki Naga dengan memanfaatkan hasil perikanan berupa ikan gabus (Channa striata) secara online dan onsite bagi beberapa orang perwakilan ibu-ibu PKK. Kegiatan ini dilakukan dengan memanfaatkan teknologi, yang bertujuan untuk meminimalisir terkena dampak virus Covid-19. Dengan adanya teknologi aplikasi zoom meeting ini, tim yang melaksanakan kegiatan lebih mudah untuk memaparkan kepada masyarakat tentang bagaimana proses pembuatan kaki naga ikan gabus (Channa striata).

Pelatihan ini dilakukan di Kelurahan Pahandut Seberang dan untuk pengolahan dilakukan di Laboratorium THP, Jurusan Perikanan, Fakultas Pertanian, Universitas Palangkaraya. Pada hari Senin, 9 November 2020, dikarenakan masih kondisi pandemic maka hanya beberapa orang saja yang mengikuti 
kegiatan secara onsite, dan Sebagian mengikuti secara online ditempat masing-masing.

Pelatihan yang dilakukan secara online untuk masyarakat di kelurahan pahandut seberang mempermudah untuk mendapatkan tutorial pembuatan kaki naga ikan gabus (Channa striata). Kegiatan ini diawali dengan persiapan pelatihan, pelaksanaan pelatihan, persiapan publikasi, dan terakhir adalah publikasi hasil pelatihan yang sudah dilakukan.

Kegiatan Pengabdian sangat membantu masyarakat dalam meningkatkan keterampilan dan pengetahuan masyarakat. Pengabdian ini sangat diperlukan masyarakat dan dalam pengolahan produk yang berbahan dari hasil perairan diperlukan untuk meningkatkan gizi masyarakat, terlebih pada masa pandemic seperti sekarang dimana imunitas tubuh sangat diperlukan untuk mempertahankan kondisi Kesehatan tubuh agar tidak mudah terserang penyakit.

Pelaksanaan kegiatan yang dilakukan pada RT 03 Kelurahan Pahandut seberang sangat didukung ketua RT dan masyarakat dilingkungan tersebut. Kegiatan pengabdian kepada masyarakat yang dilaksanakan memberikan arahan yang baik untuk terlaksananya peningkatan keterampilan kelompok masyarakat. Adapun bahan yang digunakan untuk pembuatan kaki naga disajikan pada Tabel 1.

Tabel 1. Bahan dan Fungsi

\begin{tabular}{llcl}
\hline No & \multicolumn{1}{c}{ Bahan } & Jumlah $(\mathbf{g})$ & \multicolumn{1}{c}{ fungsi } \\
& & & \\
\hline 1 & Daging ikan patin & 1000 & Bahan utama pembuatan kaki naga \\
2 & Tepung tapioka dan terigu & 500 & Bahan pengisi pembuatan kaki naga \\
& & 10 & Sebagai pemberi cita rasa \\
3 & Garam & 2,5 & Sebagai penyedap rasa \\
4 & Lada & 2,0 & Memberi aroma pada kaki naga \\
5 & Daun sop & 20 & Memberikan aroma dan rasa khas \\
6 & Bawang putih & 30 & Bahan tambahan untuk memperkaya \\
7 & Wortel & 9 & nutrisi \\
& & 900 & Sebagai penyedap rasa \\
8 & Royco & 100 & Mntuk mengempukkan adonan \\
9 & Es batu & Secukupnya & Bahan perekat antara adonan dan \\
10 & Tepung panir & Secukupnya & dengan panir \\
11 & Telur & & Menusuk adonan kaki naga \\
12 & Stik & & \\
& &
\end{tabular}

Sumber : Data Primer (2020) 

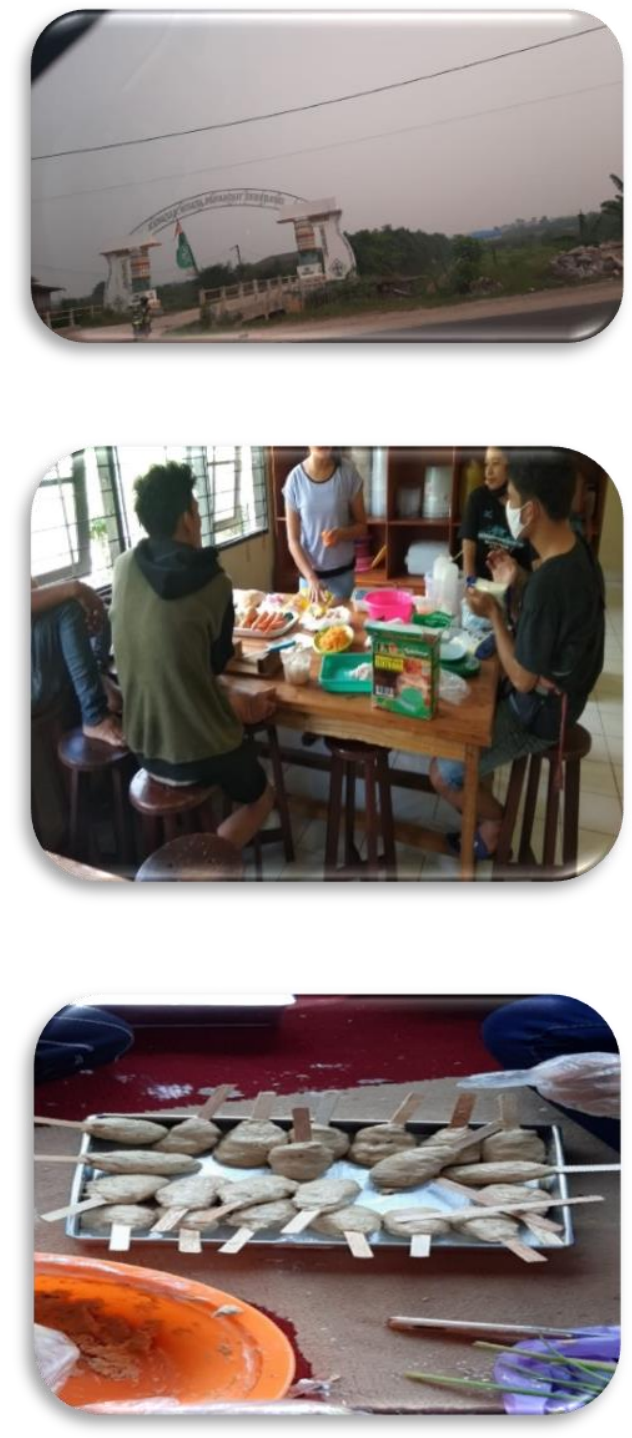
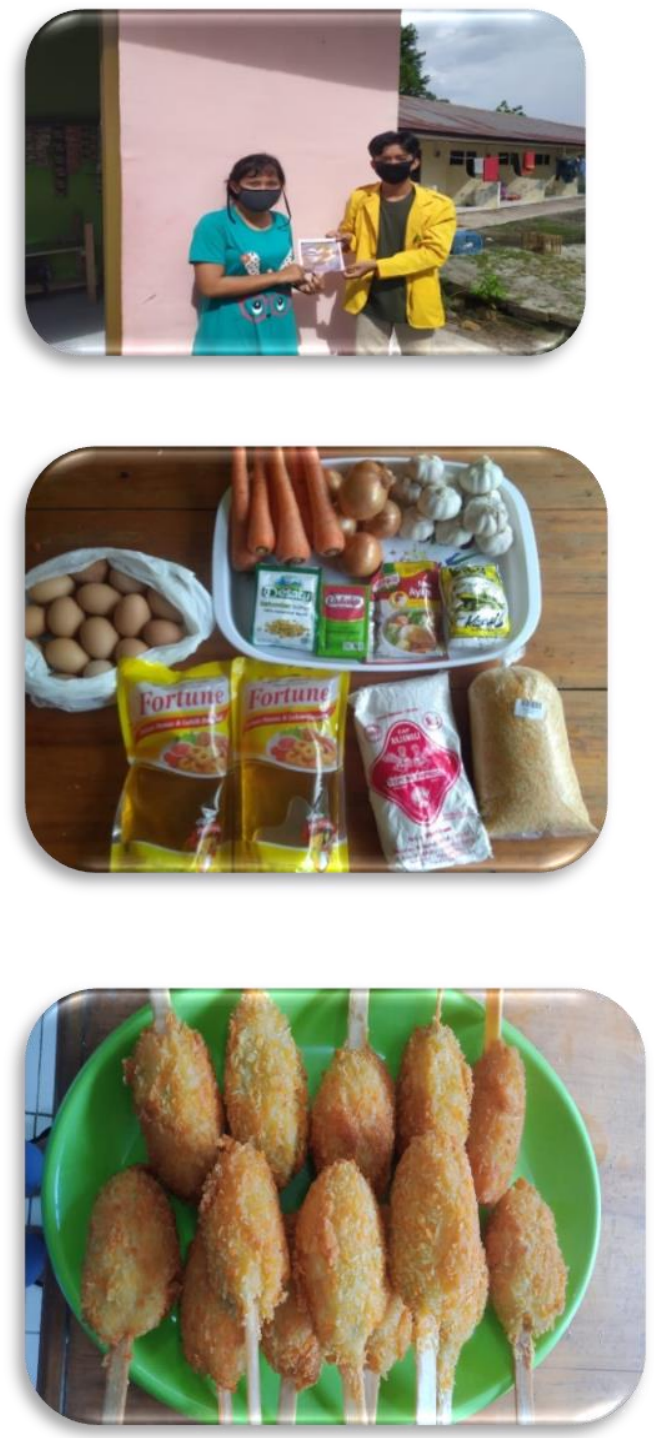

Gambar 1. Dokumentasi Pengolahan Kaki Naga

Kaki naga merupakan makanan hasil perikanan favorit semua kalangan masyarakat di Jakarta dan kota besar lainnya. Mengingat masyarakat Jakarta umumnya menyukai makanan yang praktis dan cepat saji. Keberagaman produk hasil olahan perikanan menjadikan konsumsi ikan di masyarakat menjadi semakin meningkat. Proses produksi pembuatan kaki naga ikan dimulai dari penerimaan bahan baku berupa fillet ikan yang masih segar, kemudian dilanjutkan dengan proses penggilingan fillet ikan hingga berbentuk pasta, pengadukan adonan dengan penambahan bahan baku lainnya, pemasakan, pencetakan menggunakan tangan dan sendok atau garpu, penggorengan secara deep frying, penirisan di meja penirisan, batter, breading, ditusuk dengan sumpit, pengemasan, dan pembekuan. Produk kaki naga merupakan salah satu bentuk diversifikasi produk hasil pertanian, terutama perikanan. Biasanya kaki naga dimanfaatkan sebagai makanan penunjang atau pelengkap dari 
makanan pokok. Kaki naga yang praktis serta cepat disajikan dan kaya akan kandungan gizi menyebabkan makanan ini banyak digemari baik dari anak kecil hingga orang dewasa. Selain itu produk ini sifatnya gurih sehingga dapat membantu mereka menambah nafsu makan, dengan bentuk yang menarik membuat produk ini menarik konsumen untuk membelinya. Pemilihan usaha kaki naga dilakukan karena bahan baku utama berupa fillet ikan mudah didapatkan. Sedangkan jumlah permintaan otak-otak dan kaki naga cenderung bertambah tiap tahunnya, sehingga dapat memberikan pemasukan yang konstan. Selain itu teknologi untuk memproduksi kaki naga mudah didapat.

\section{Prosedur Pembuatan}

Prosedur pembuatan kaki naga dari jenis ikan patin adalah sebagai berikut :

1. Campur ikan, air es, bawang putih, dan tepung tapioka. Aduk sampai rata.

2. Garam ditambahkan kedalam lumatan daging ikan sambil terus diaduk hingga berbentuk adonan yang lengket / kalis.

3. Tambahkan 1 butir telur, 1 sdt merica. Tiap-tiap penambahan bahan diuleni hingga homogen.

4. Tambahkan tepung tapioka dan terigu masing-masing sebanyak 250 gr dan uleni hingga homogen

5. Tambahkan daun sop yang telah diiris / dirajang dan diuleni hingga tercampur rata.

6. Bentuk adonan agak bulat lonjong dan dikepalkan dalam stick

7. Lakukan pengukusan menggunakan dandang selama +10 menit

8. Angkat dan dinginkan, kemudian lakukan pelapisan tepung roti.

Kaki naga dalam bentuk seperti ini bisa disimpan dalam lemari pendingin /freezer atau dapat langsung digoreng. Kaki naga merupakan hasil olahan yang cukup digemari yang saat ini tengah dikembangkan oleh masyarakat perikanan. Karena kaki naga merupakan diversifikasi dari kamaboko yang merupakan bahan untuk surimi. Maka kaki naga dapat mengikuti SNI surimi, berdasarkan SNI Nomor 01-2693-1992, maka kaki naga adalah diversifikasi dari kamaboko, yang memiliki standar mutu dengan elastisitas berkisar antara 26,73\% - 65,66\%; kadar abu antara 0,44\% 0,69\%; kadar protein antara 10,44\% - 16,40\%; dan kadar lemak antara 0,09\% - 0,55\%. Gizi dari kaki naga ikan tergantung dari jumlah ikan yang digunakan dalam adonan, dalam pengolahan hasil perikanan dimana makin banyak jumlah ikan dibandingkan tepung maka gizi produk akan semakin baik. Perbandingan tepung dan ikan yang diajarkan ke kelompok mitra PKM ini adalah 1:2, artinya jika menggunakan tepung 100 gr maka ikan yang digunakan adalah 200 gr. Pelaksanaan kegiatan PKM ini bertujuan menggalakan masyarakat untuk makan ikan dalam porsi yang banyak terutama untuk ibu-ibu hamil dan anak-anak balita mengingat pentingnya kandungan protein dan asam lemak omega-3 yang adalah komponen kimia pangan yang khas pada ikan, dimana lemak ikan banyak mengandung asamasam lemak omega tiga dan enam seperti ETA, EPA dan DHA.

\section{KESIMPULAN}

Pembinaan dan peningkatan pengetahuan bagi masyarakat di kelurahan Pahandut seberang memberikan manfaat yang sangat berguna bagi masyarakat dalam rangka meningkatkan gizi dan kesejahteraan masyarakat, dan dengan adanya diversifikasi dari olahan ikan air tawar ini juga akan memperkenalkan Kota Palangkaraya sebagai kota yang memiliki sumberdaya hasil perikanan terutama perikanan air tawar yang cukup melimpah dan bermaanfaat untuk kesehatan masyarakat. Kaki naga ikan sebagai makan sehat, bergizi dan mempunyai rasa yang lezat yang bisa dikembangkan sebagai skala usaha rumah tangga. 


\section{DAFTAR PUSTAKA}

Agustini, T.W. \& F. Swastawati. 2003. Pemanfaatan Hasil Perikanan Sebagai Produk Bernilai Tambah (Value-Added) dalam Upaya Penganekaragaman Pangan. J. Teknologi dan Industri Pangan Vol XIV, No. 1. 74-81

Biro Pusat Statistik. 2017. Kecamatan Pahandut Dalam Angka. Palangka Raya.

Dotulong Verly dan Montolalu Lita. 2019. Jurnal Media Teknologi Hasil Perikanan Vol. 7, No. 3. 88-92

Monografi Kelurahan Pahandut. 2017. Kelurahan Pahandut, Kota Palangka Raya.

Nugroho Aditya, Swastawati Fronthea, Anggo Dwi Apri. 2014. Pengaruh Bahan Pengikat Dan Waktu Penggorengan Terhadap Mutu Produk Kaki Naga Ikan Tenggiri ( Scomberomorus Sp.) Jurnal Pengolahan dan Bioteknologi Hasil Perikanan Volume 3, Nomor 4, Halaman $140-149$.

Rahmawati, F. 2012. Aneka ragam Pengolahan Ikan. Materi Kegiatan Pemberdayaan Sosial untuk Kegiatan Pendidikan Alternatif dalam Pengolahan Potensi Lokal. Kerjasama Kemeneterian Pembangunan Daerah Tertinggal dengan Fakultas Pertanian UGM. Sumba Tengah, 13-16 Agustus 2012. 